\title{
How Should We Manage China's National Parks? A Comparative Analysis between National Parks in China and the US
}

\author{
Linghong Kong1,2, Yangcui Ning ${ }^{3 *}$, Long Chen ${ }^{3}$ \\ ${ }^{1}$ Global Environment Institute, Beijing, China \\ ${ }^{2}$ Nelson Institute for Environmental Studies, University of Wisconsin-Madison, Madison, WI, USA \\ ${ }^{3}$ Beijing Municipal Research Institute of Environmental Protection, Beijing, China \\ Email: lhkong80@gmail.com, *ningyangcui@163.com
}

How to cite this paper: Kong, L.H., Ning, Y.C. and Chen, L. (2018) How Should We Manage China's National Parks? A Comparative Analysis between National Parks in China and the US. Open Access Library Journal, 5: e4030.

https://doi.org/10.4236/oalib.1104030

Received: October 13, 2018

Accepted: December 23, 2018

Published: December 26, 2018

Copyright $\odot 2018$ by authors and Open Access Library Inc.

This work is licensed under the Creative Commons Attribution International License (CC BY 4.0).

http://creativecommons.org/licenses/by/4.0/

\begin{abstract}
This paper analyses the differences between policies in Chinese and American national parks, including the role of communities, the permitting and reservation system, and camping. It also describes additional recommendations related to developing community-based tourism, the e-commerce market, and data statistics tools. What is the best way to support communities economically at the boundaries of national parks? The American experience shows that tourism and ecotourism can be an important economic opportunity for local communities in China. Communities can provide tourism services. They can bring in revenue by operating facilities like hotels, restaurants, groceries, gas, and transportation services. While establishing Chinese National Parks, the government will need to pay close attention to developing and supporting economic development in and near parks, with a special emphasis on building strong relationships with communities. By comparing case studies of American and Chinese national parks, this paper will explore how communities can drive economic development.
\end{abstract}

\section{Subject Areas}

Environmental Sciences, Natural Geography

\section{Keywords}

Tourism, Community Economic Development, Community-Based Tourism, E-Commerce, National Parks, Ecological Protection

\section{Introduction}

National Park is Category II in IUCN Protected Area Categories System. The de- 
finition is that large natural or near natural areas set aside to protect large-scale ecological processes, along with the complement of species and ecosystems characteristic of the area, which also provide a foundation for environmentally and culturally compatible spiritual, scientific, educational, recreational and visitor opportunities (From IUCN website).

In the United States, National Parks are designed to protect ecosystems, promote environmental education, and provide the public with opportunities for recreation. They are part of a broader nationwide public lands system that includes national forests, state parks, and so on. Starting in 2011, China put forward the concept of establishing a National Park system with a goal of operating pilot National Parks by 2015. As a result, various agencies and experts from around the world have begun to design a template for institutional and capacity building for National Parks in China, with a specific focus on identifying strategies suitable to China's national conditions. At present, China has ten national park pilot projects, including Sanjiangyuan, Northeast Tiger and Leopard, Giant Panda, Shennongjia, Wuyi Mountain, Qianjiangyuan, Hunan Nanshan, Beijing Great Wall, Qilianshan and Shangri-La Putatso [1] [2] [3]. The National Development and Reform Commission of China (NDRC) and several experts are now working on developing management systems and institutional reforms in order to support and promote effective national park management in China. Su Yang (2016) also addresses the difficult problem of solving the relationship between land, land use, and people.

In the United States, National Parks are part of a broader ecological protection systems (national forests, state parks, protected areas, etc.), and they protect ecosystems and promote environmental education while also providing the public with opportunities for recreation. Since 1916, the National Park Service (NPS), a bureau of the U.S. Department of the Interior, has been entrusted with the care of National Parks (http://www.nps.gov/). The NPS manages the 417 park units (as of 2017) of the National Park System [4] [5]. The following table shows detailed differences between China and U.S. (Table 1).

Table 1. Differences between China National Park and U.S. National Park.

\begin{tabular}{|c|c|c|}
\hline Differences & China NP & U.S. NP \\
\hline Number & 10 (Just experimental unit) & 59 NP/417 Units \\
\hline $\begin{array}{l}\text { Management } \\
\text { Mechanism }\end{array}$ & In building & A whole system \\
\hline Funding & Local government & $\begin{array}{l}\text { federal treasury funds } 87.7 \% \text {, visitor } \\
\text { fees } 6.2 \% \text {, } \\
\text { philanthropic donations } 3.2 \% \text {, } \\
\text { and concession franchise fees } 2.9 \%\end{array}$ \\
\hline $\begin{array}{c}\text { Visitor Spending Effects } \\
\text { Statistics }\end{array}$ & In building & More than 25 years \\
\hline Employees & In building & More than 20,000 strong \\
\hline History & In building from 2016 & Above 100 years \\
\hline
\end{tabular}


The operation of the NPS is mainly supported by the general federal treasury. Its budget comes from four sources: general federal treasury funds, visitor fees, philanthropic donations, and concession franchise fees. The NPS reported that the 2015 annual budget for the National Park system is approximately $\$ 3.0$ billion, and most of this funding comes from the general federal treasury, accounting for $87.7 \%$ of the total budget. Tourism revenue accounted for $6.2 \%$, franchise fees made up 2.9\%, and philanthropic donations amounted to $3.2 \%$ [6]. The three other revenue sources play important roles, even though they are relatively small in comparison to federal funds. This budget is used to support the overall operation of NPS, including recreation, construction, preservation and protection of resources, the historic preservation fund, youth education, volunteer programs, and other expenses.

Advocates proudly declare that National Parks are one of America's best ideas [6] to share with the world. In the U.S., National Parks are one element of a much larger effort to protect ecosystems and natural resources, and also one of the most important ways to educate the public about the importance of protecting the world's natural ecological systems. National Parks as a whole are the most popular tourist destination in the U.S. [7], attracting crowds of domestic and international visitors. In 2016, National Park Service received 331 million recreation visits [8]. This is an increase of 24 million from 2015.These visits can help the public appreciate natural scenery and value the protection of natural resources.

The popularity of park tourism provides more opportunities to bring in income for local communities, especially "gateway" communities (defined as those within 60 miles of a park) [9] [10] [11]. For example, most domestic and international visitors stayed in gateway communities surrounding the national park during their visit. Gateway communities can receive revenue from visitors through lodging, restaurants, bars, stores, and gas and transportation services. Often, parks will entrust franchises or concessionaires to manage hotels, restaurants, camping sites, gift shops, and tourism operators. In return, concessionaires pay annual franchise fees to the NPS that are based on the value of the contract to the concessionaire [6]. The franchises themselves generate revenue, most of which benefits local communities. Residents from local communities can also get a part-time or full-time job in franchise enterprises. There is evidence that government spending on National Parks is a highly effective method to promote economic development in the communities surrounding parks. NPS studies have shown that for every federal government dollar spent on the national parks, $\$ 10$ is generated for local businesses and communities, resulting in a total of almost $\$ 30$ billion in economic activity associated with the national parks in 2014 [7].

Services within national parks (tourism, hotels, restaurants, etc.) attract millions of visitors from across the nation and around the world, and this number is increasing year by year. The NPS has been measuring and reporting visitor 
spending and economic effects for more than 25 years [12]. Figure 1 shows that annual visitation remained relatively constant between 2013 and 2016. There was a small dip in 2013 due to the after math of Hurricane Sandy and the two-week federal government shutdown in October [13], with a decline in visitation of 9.1 million (3.2\%) compared to 2012. Overall, visitors spend time and money in the gateway communities and generate a considerable amount of economic income for local communities.

According to NPS statistics, in 2016, Visitors to National Parks spent an estimated $\$ 18.4$ billion in local gateway regions [12]. The lodging sector was the largest contributor to this figure, with $\$ 5.7$ billion in economic output contributed directly to local gateway economies nationally. The second-highest sector was restaurants and bars, with an income of $\$ 3.7$ billion [8].

The U.S. National Park system has been in place for 100 years. In China, however, the establishment of national parks is just beginning. In 2008, China's Yunnan Province established a few national parks. Ultimately, however, some Chinese experts think they should not be classified as national parks because they lack certain important functions with regard to national treasures, national administration, public service, land property rights, park laws, and public education [14] [15] [16].

Since 2011, China has worked to establish a national-level system of National Parks. Many experts from around the world began to research the management systems of national parks, especially case studies from the U.S., Brazil, Germany, Japan, New Zealand, South Africa, and Thailand. As a result of this research, the Chinese government has decided to follow the United States model to establish the Chinese National Park system and to use these lessons and experiences from U.S. National Parks to advance China's park goals. As stated earlier, there are many communities in protected areas in China. By the end of 2014, a total of 12.56 million residents lived in 1657 Nature Reserves across China [17]. Thus, working with communities and developing local economies is a critical challenge. Establishing and maintaining strong communications and good cooperative

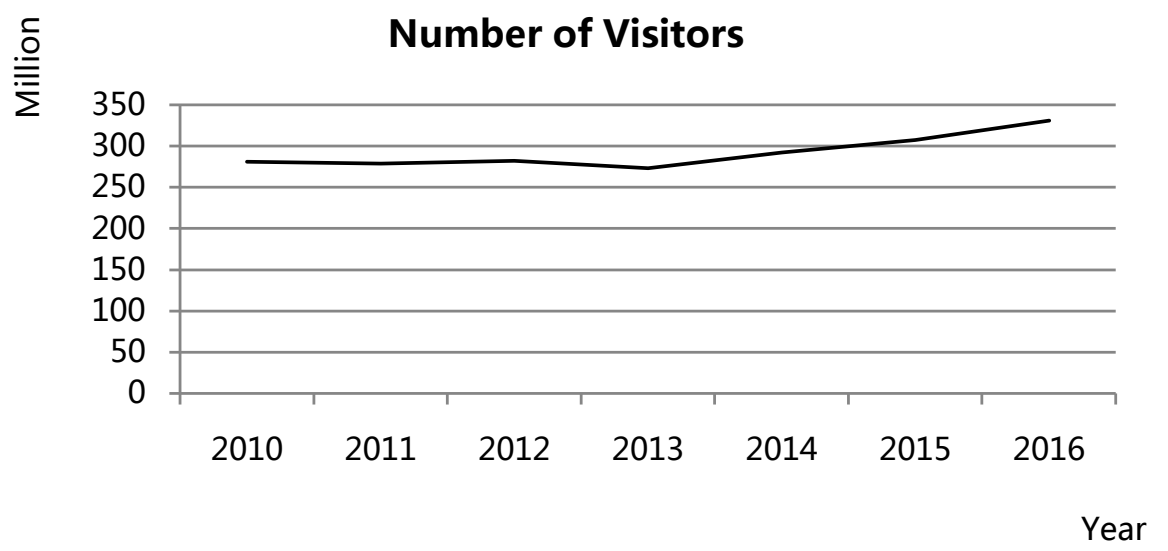

Figure 1. Number of visitors to National Park system from 2010 to 2016 (Data source: nps.gov). 
relationships with surrounding landowners is vital to wildlife conservation and community economic development, according to Wan Xusheng of South-North Institute for Sustainable Development in 2016.

Communities will be a key part of successful national parks in China. They can rely on some natural resource use and also help with natural resource protection. Therefore, we should consider how to balance benefits for all stakeholders-government, community, enterprises, and others-as China begins to establish national parks. How can communities get economic opportunities through park tourism? How do they work with the park service to ensure park protection? Tourism, especially ecotourism, will be an important way for local communities to generate revenue. Community participation is considered to be a particularly important concept for sustainable tourism operations [18]. Communities can operate the restaurants, hotels, stores, bars, transportation service, tourism and education services, and so on. They also can develop special tourist products, such as non-timber forest products, handicrafts with social and cultural features, and value-added agriculture products (for instance, intentional cultivation of non-timber forest products). These types of activities are called community-based tourism [18] and will be a critical tool for natural resource conservation and community development in China.

\section{Method}

Comparative analysis of Chinese and American national parks can provide valuable lessons for establishing community management systems and conservation policies in China. Some national parks may have different functions which will be important to consider, especially since China is directly converting nature reserves into national parks. The U.S. has already had a century to explore the dynamic between ecological protection and economic development.

This paper compares the differences in visitor planning, community economic development methods, visitor spending, and admission tickets between Chinese and American National Parks through some statistical analysis and case studies. The comparison can reveal best practices for Chinese national parks and cooperation between park authorities and communities. For example, this paper compares the visitor design and planning and admissions fees between Chinese and American national parks. Data from visitor spending can show that the best businesses that community can open are hotels and restaurants. The study also tries to identify the key factors that restrict conservation and economic development in national parks.

One of the methods is data analysis of visitor spending, admission fee policies, and the permitting system. U.S. national park data and information comes from the NPS website, relevant literature, and experts' research [4] [7] [19]. Data on China's national parks and protected areas come from a 2015 Global Environmental Institute (GEI) field investigation by my colleague and myself and our project experiences. Another method is case studies. This paper chooses four na- 
tional parks, two from the U.S. and two from China, and makes a comparative analysis in tourism design and planning, community economic development from tourism, visitor spending, and admission fees. For example, as time passed, Yosemite and Rocky Mountain removed certain tourist facilities within the parks, especially Rocky Mountain. These facilities were directly removed while camp grounds and parking lots were built and local communities constructed tourism service facilities. This change provided a development opportunity for local people. Sanjiangyuan and Putatso National Parks are having these problems now. This comparison study can explore U.S. national park practices and recommend solutions for communities and parks in China.

\section{Case Studies}

Yosemite is one of America's oldest national parks, established in 1890. The management goals of the park have changed over time. For example, hotels were built directly at scenic spots in early years, but now the management goal is to leave these scenic spots unimpeded. Yosemite's visitor numbers have steadily increased over time and were around 5 million in 2016 (https://irma.nps.gov). Yosemite conducted a comprehensive survey in July 2009, with $93 \%$ of visitors reporting that their primary purpose in visiting the park is "viewing scenery". According to the survey, in the summer high season $75 \%$ of visitors are American (62\% of whom are from California) and 25\% are international [20].

In contrast, Rocky Mountain National Park, which was established in 1915, is an excellent example of a park that relies on gateway communities for almost all of its services. With no lodges of its own, the Park and has a close relationship with the gateway communities, where most visitors to the park stay. In the 1990s, Rocky Mountain hired a planner with the specific job of not only working on park planning but also to working directly with gateway communities to help them plan their tourist-oriented initiatives. The net result is that the vast majority of services are provided within the gateway communities, with a management goal of a seamless experience from outside to inside the park.

Potatso National Park, in China, was established in 2008. It is located in Diqing prefecture, Yunnan Province, China. Advocates label Potatso the first "national park" in China. It is not truly a national park, differing from the national parks currently being developed by the Chinese national government. It isn't managed and funded by the central government, but instead is managed by Diqing prefecture. Through cooperation, field trips, and interviews in 2015, GEI obtained information about tourism planning and community activities at Potatso.

In 2015, Sanjiangyuan National Park became one of nine national park pilots established by the central government. The park includes Qinghai HohXil National Nature Reserve, as well as part of Sanjiangyuan National Nature Reserve. Since 2013, GEI worked with the Sanjiangyuan Management Bureau on a project to balance ecological protection and community economic development in $\mathrm{Gu}$ - 
oluo and Yushu prefectures when it was called Sanjiangyuan Nature Reserve. GEI has under taken various projects together with local communities and park authority. For instance, GEI supported Longge Village to establish cooperation on environmental protection and handicraft production. Longge Village is located within the Nianbaoyuze Natural Reserve, which is one part of Sanjiangyuan. GEI also helped another village provide tourism service training. These are demonstrations from GEI and park authority.

\section{Comparative Analysis}

\subsection{Permitting System and Reservation System}

Based on the experience of U.S. national parks, the permitting system and reservation system is an effective method for conservation of natural resources. For lower impact on the environment, particularly wilderness areas, most parks have formulated Backcountry Management Plan [21]. This plan is the primary policy for managing visitor use and resource protection in the backcountry. It includes a detailed permitting system and reservation system. The permitting system controls the number of people that go into the wilderness area, and visitors are limited to ensure that there is not overcrowding. Camping is a popular way to vacation in the wilderness of national parks. Camping is considered to have a lighter impact on natural resources [22]. There are limits on the number of days campers can stay during the busy summer months in order to protect the natural resources. The goal of permitting and reservation systems is to limit and control the number of people, especially during the summer high season. But some tickets are held as first come, first serve. Each park is required to set a maximum number of backcountry users, and more than this number each day is not allowed to enter.

In China, there is no reservation system in parks and other protected areas, even in popular parks, and no permitting system. The public is not allowed to enter wilderness areas. If under limited the number of the people, park may open the wildness to public. Hence, China's national parks should formulate the national park laws or regulations, set up permitting systems, and adopt a reservation system according to the condition of every park. Since China often times has too many people visiting their national parks, buying a permit and making a reservation will be the best way to ensure less impact on natural resources in popular parks. These reservations would be open to all people who want to book them; anyone can go so long as they get a reservation and pay the fee. This would also provide important income for tourism services.

If you want to visit the wilderness, you must buy a permit to enter. Visitors can stay in a campground. The American camping system is well-developed, including the use of informational signs, maps, and other related facilities and management actions for car camping or backcountry camping. Campgrounds are suitable for different groups; this camp is generally inside the park, and there are generally dozens to a few camping sites. Usually, each site has one or more 
parking spaces, a fire pit, a picnic table, and a tenting pad. Many campgrounds have drinking water, bathroom or flush toilets, hot showers, and laundry as well as shops and other facilities (for campfire wood, ice cream, etc.) in the vicinity of camping sites [4] [23].

This is a successful mode of tourism for U.S. National Parks. Many people enjoy camping in American parks, even international visitors coming for the first time. It can be an exciting and cheaper way to travel. In some popular campsites, it is possible to reserve as many as six months ahead. Camping is an indispensable part of the visitor spending, although it is a small proportion. 2012-2016 national park visitor spending effects reports showed, since 2013, it is about $2.5 \%$ of the total of visitor spending, with a gradual increase (Figure 2 ).

China should establish campsites in the wilderness of national parks. Camping has already been a trend even without government guidance in China. But the most important thing is to establish the permitting and reservation system. In addition, China will need better service facilities in campgrounds so that visitors can fully enjoy the park scenery. For example, when GEI visited Putatso National Park in 2015, our staff went into the park by shuttle and came back out again soon afterward. This lack of a deeper experience reduces the original intention of the establishment of the national park. Camping can attract many visitors. It can drive the development of tourism industry, such as hotels, restaurant, stores and others.

\subsection{Community Economic Development from Tourism}

National parks are not only a piece of land designed for environmental protection, they also serve recreational and educational purposes. They should also provide services to the community and the public. Visitation to the park is the primary recreational function of parks. Meanwhile, communities inside protected areas are an important factor impacting sustainable development of tourism [24] [25]. Tourism development can be a good way to improve the quality of life [26] and the economy of local communities [27] [28]. Communities also are protectors like park authorities. When parks work with local communities to

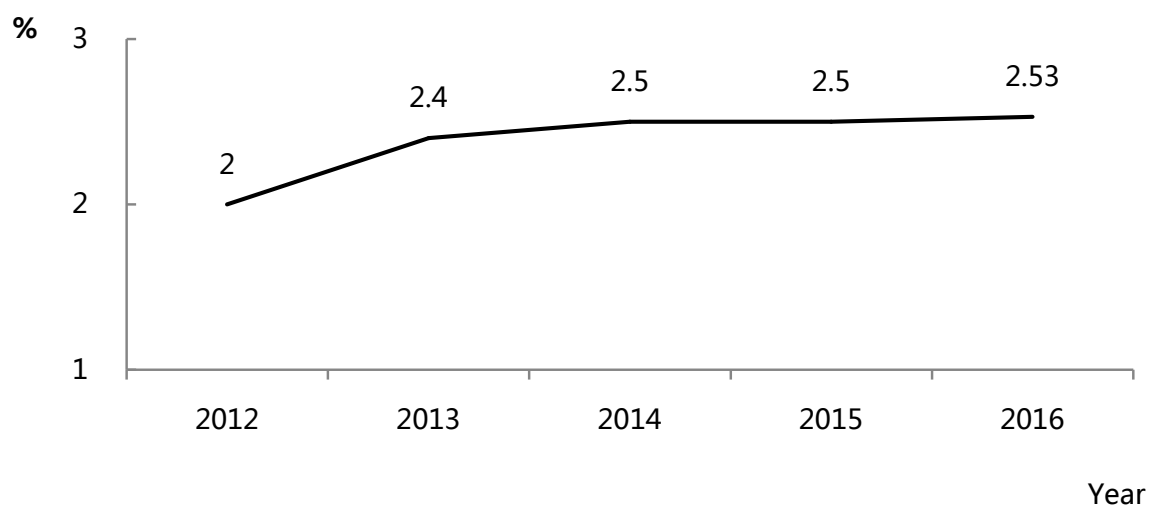

Figure 2. Camping fees in the visitor spending (\%) (Source: 2012-2016 National park visitor spending effects). 
protect the environment and improve their economy, protection of park resources can begin faster and be more effective. In the past thirty years, the problem of effective community economic development has been plaguing China, and most protected areas in the past decade have started to recognize the problem. In designing projects, parks now put greater emphasis on community economic development. However, there are still many deficiencies compared to the U.S. National Parks. The biggest difference is that the way of promoting community economic development is different.

Park visitors can choose many different types of trips in National Parks. Most of them will stay in gateway communities, utilizing hotels, restaurants, stores, gas stations, and other businesses. In the NPS visitor spending reports (2012-2016), visitors are grouped into seven distinct segments to explain differences in visitor spending: local day trip, non-local day trip, NPS lodge, motel outside park, camp outside park, and other [8] [12] [13] [29] [30]. The reports analyze the effect of visitors' economic activity in communities near a park or recreation area, specifically the effect on business sales, jobs, and income [8]. Each state and each park unit has separate statistical data. There is a statistical tool to show visitor spending data for this year on the NPS website (http://www.nps.gov/). Another set of statistics shows that communities can get significant revenue from visitor spending. For example, in 2016, 331 million park visitors spent an estimated $\$ 18.4$ billion in local gateway regions while visiting NPS lands, an increase of $8.9 \%$ over last year.

Many parks in the United States have changed their tourism management practices over time, based on the lessons they have learned from various types of tourism projects. For instance, Yosemite NP has moved away from building hotels directly at scenic spots, and now the park only manages four campgrounds. This change made most visitors stay in gateway communities. According to the 2015 statistics, less than $5 \%$ of the visitors to the park actually stay overnight [12]. For example, of Yosemite's 4 million annual visitors, only about 150,000 stay overnight in the park, and of these, only about 50,000 go into the back country. Many visitors stay in one of the gateway communities. Another example is when GEI hired experts to study the U.S. National Parks in 2015, the expert Deborah Seligsohn said in her report that Rocky Mountain National Park is an excellent example of a newer park that relies on its gateway communities for almost all of its services [22]. The park has a good relationship with local communities. The Park has no lodges and most visitors to the Park stay in one of two Gateway Communities. Visitors can take shuttle bus to visit the park. We can see from two cases, even though there is not a community living inside the national park itself, NPS still pays attention to good relationships with communities. It is important that China develop similar relationships with the gateway communities of our National Parks.

China's national parks or protected areas are still grappling with how best to do this, and GEI saw this as the two national parks we surveyed. Putatso Nation- 
al Park (http://www.puda-cuo.com/), which was established in 2008, simply gave the community compensation and developed the "Putatso National Park Community Implementation Program from Tourism". The fund for community compensation is more than 500 million RMB each year. The park signed a contract with the communities on a five-year basis, and it must enact compensation standards according to distance from the park. In the second five years, the community residents did not agree to the amount of compensation and demanded more money and supports. This is because they saw the tourism income increasing over time in the park while their lifestyle and income failed to get better. They needed the change. The park had no choice but to agree to this.

There is a big drawback to this one-time compensation. Specifically, it is easy to cultivate people's dependence. In planning, designers should take into account development of the community direction in the future and gradually guide the community economic development, as Rocky Mountain National Park did. Another drawback in Putatso is the trail planning. The tour itinerary is too simple. The route is a wooden road only about 15 kilometers long. There are few hiking trails, and even though there are some trails, the park doesn't provide these details in the tour map. In a day, visitors can see the main scenic spots. The park does not give visitors enough reasons to stay, so the community cannot rely on tourism to generate revenue. It also does not give visitors more freedom; they are restricted to taking the shuttle in and back.

Sanjiangyuan National Park is a vast area with scattered herdsperson. It includes ten protected area. In recent years, tourism has become more popular in this area. Some sub-protected areas carried out tourism planning, and every protected area had a different project. One of them, Nianbaoyuze Natural Reserve area, carried out tourism planning in Fairy Lake a few years ago. This project is now in progress. However, the surrounding herders didn't understand the project. Even though they wanted to make changes to follow the tourism project, they did not know how to do. They want to engage in tourism-related industries, but one problem is a lack of technology while another is not enough money. GEI worked with the Sanjiangyuan Authority to develop the project on environmental protection and community economic development. Under GEI's help, herders set up a cooperative that produced Tibetan traditional handicrafts in preparation for tourist visitors. However, during the tourism development, the park authority did not take into account the economic interests of the herdsmen, did not appropriately plan for the community's economic development, or develop corresponding rules to guide the community in how to develop their own economy. Another example is Make River Forest protected area in Sanjingyuan Nature Reserve, with a different community approach. They chose some herder families to open family inns, supporting each project with 200,000 RMB and letting them to transform their own houses into inns. These inns will have Tibetan characteristics such as Tibetan furniture, Tibetan patterns, and Tibetan diet. Although there is financial support, the herdsmen lack some related 
training, such as tourism reception, guesthouse health and management, food hygiene and safety requirements, the provision of tourism products, transport services, or guides and other travel services. This poses a barrier for herding families who know they can open a hotel to make money, but may not have the appropriate skills and training to run it effectively.

From the comparison, it is possible to see that community economic benefits come from hotels, restaurants, groceries, souvenir shops, and so on. The NPS visitor spending report draws on data that has been continuously collected for 25 years. I analyzed the data from 2012-2016 (Figure 3), in particular subdivided into hotels, restaurants, groceries, gas, transportation, admission fees, souvenirs and other fees. Figure 3 shows that the economic income of each industry continues to increase steadily. Two of them, hotels and restaurants, have the highest earnings. This means hotels and restaurants are indispensable industries for park tourism. China has not paid enough attention to community economic development, especially communities from inside and outside parks. These are the deficiencies in China's protection and management system. Hence, when the park authorities undertake tourism planning, parks should more fully take into account the surrounding communities and give them more room for development, such as planning some hiking trails and changing the administration of admission fee (discussed in the following section). This planning should also encourage visitors to stay more days inside or outside the park.In my opinion, this is an important lesson to be learned from the U.S. NPS.

\subsection{Admission Fee Criteria}

In America, park admission fees are very cheap. Their visitor-friendly regulation bases fees on the number and types of vehicles, between about $\$ 10$ to $\$ 30$, rather than the number of visitors. The parks also have a flexible charging policy. Every park has a day pass, seven-day pass, annual pass, and others. Yosemite National

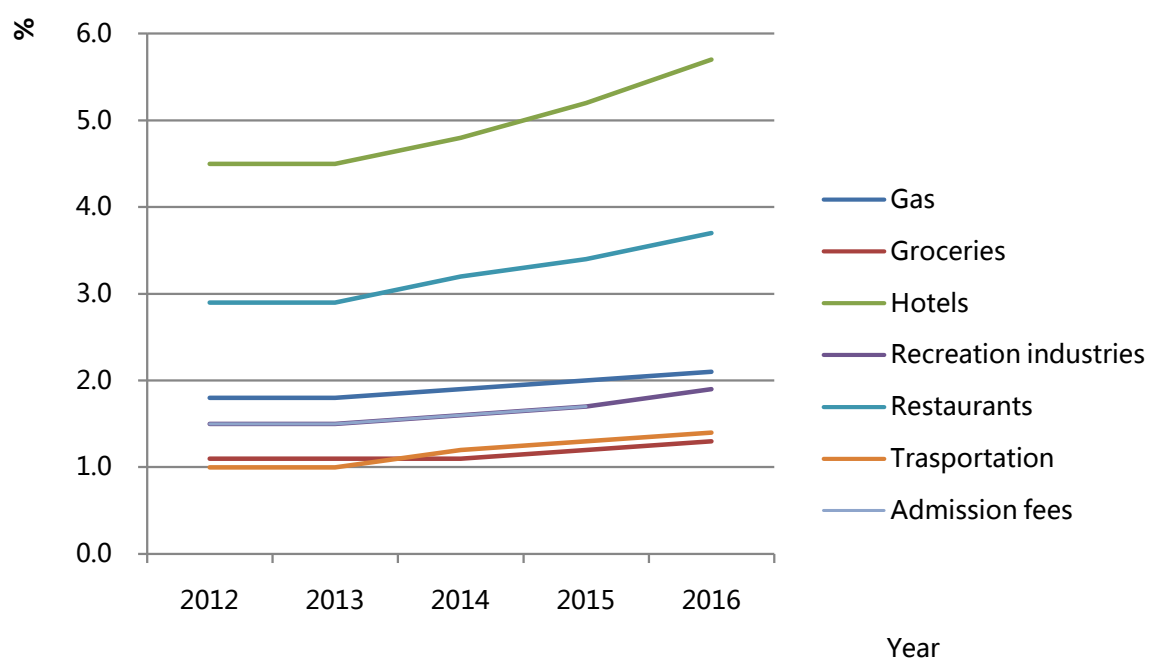

Figure 3. 2012-2016 Distribution categories by visitor spending (Source: NPS Visitor Spending Effects Reports). 
Park can be an example to illustrate this policy. A seven-day pass if entering via non-commercial car, pickup truck, RV, or van with 15 or fewer passenger seats is $\$ 30$ per vehicle (no per-person fee); if entering via motorcycle is $\$ 25$ per motorcycle (no per-person fee); if entering via foot, bicycle, horse, or non-commercial bus or van with more than 15 passenger seats is $\$ 15$ per person age 16 and older. If a commercial vehicle enters the park, the entrance fee is different (please see the following Table 2). School visits for educational purposes are free of charge [31]. In addition, the ticket price in U.S. parks is usually the total price, with no additional charge for scenic spots. With a range of ticket options, visitors can easily plan tours of various lengths and choose to stay either inside or outside of a park without worrying about additional admission fees. The charging policy encourages visitors to stay more days to see the entire park. During their stay, visitors will use lodging, restaurants, shopping, transportation service, gas service, and so on. The community can provide these services to earn revenue.

Since March 1, 2015, the admission fee of Yosemite has increased (see Table 2). In the NPS's 2015 Entrance and Camping Fee Increase Frequently Asked Questions, the agency explained why Yosemite raised the admission fees. Yosemite's previous admission fees have been in place since 1997, when a seven-day pass was increased from $\$ 5$ to $\$ 20$ per vehicle [32]. According to the U.S. Bureau of Labor and Statistics, \$20 in 1997 is equivalent to \$29.64 in 2014 (CPI inflation calculator, http://www.data.bls.gov/). This fee change allows Yosemite to increase the admission fees to maintain consistent revenue. These increased fees are used for park projects that directly benefit visitors, such as it used to the tourism facilities, the maintaining of hiking trail, campsite construction, etc.

Table 2. Admission fees criteria of Yosemite National Park (All data comes from the NPS website).

\begin{tabular}{lc}
\hline \multicolumn{1}{c}{ Type of Vehicle } & Admission Fees (\$) \\
\hline Seven-day pass & 30 \\
$\begin{array}{l}\text { Non-commercial car, pickup truck, RV, or van with } 15 \text { or fewer } \\
\text { passenger seats }\end{array}$ & 25 \\
Motorcycle & 15 \\
$\begin{array}{l}\text { Foot, bicycle, horse, or non-commercial bus or van with more than } 15 \\
\text { passenger seats: }\end{array}$ & 125 \\
Commercial sedan (up to six seats) & 200 \\
Commercial van (7 - 15 seats, regardless of occupancy) $\$ 15$ per person) \\
Commercial mini bus (16 - 25 seats, regardless of occupancy) \\
Commercial motor coach (26 or more seats, regardless of occupancy) \\
Annual pass (12 months) \\
$\begin{array}{l}\text { Yosemite pass } \\
\text { America the Beautiful-National Parks and Federal Recreational }\end{array}$ \\
Lands Annual Pass
\end{tabular}


The fees for China's scenic spots (accounting for the proportion of national average income) are the highest in the world [33]. The admission fee is the relatively higher than other countries, and most Chinese people can't visit national parks because the high admission fee. For example, Putatso National Park' admission fee is $\$ 35$ per person in 2015 and increased to $\$ 40$ per person (including the tour transportation and the entrance fee) in 2016. This is a little expensive for most Chinese people. Data from China's National Bureau of Statistics shows that China's per capita disposable income is \$3463 USD in 2015 (21,966 RMB with an exchange rate of 6.3at the end of 2015) [34] [35]. The park's admission fee accounts for $1 \%$ of an individual average annual income in China. One of the functions of national parks is to serve the public. If most people can't afford to visit national parks, the parks will lose their educational and recreational meaning.

Chinese admission fees are a usually a day pass per person. This results in visitors simply browsing park offerings without an in-depth experience. But some scenic spots are now charging multi-day admission fees like U.S. national parks. Fairy Lake scenic spot applied this policy inside Sangjiangyuan National Park. Its three-day pass is $120 \mathrm{RMB}$ per person. This is a good change for Chinese national park.

Based on the above comparison of admission fees for American and Chinese national parks, this factor is important for the Chinese National Park system. The number of visitors should not be limited by the price level, but rather parks should instead apply a regulatory system to control tourist numbers, such as a reservation system and daily tourist flow restrictions. If visitors do not have enough time, they will not consider entering a second time or staying in the community around the national park. As a result, the community would lose many income opportunities, such as from hotels, restaurants, stores, and so on.

Another difference is that there are extra fees besides the admission fee in China. Visitor need to pay the transportation fee, cable car, and other tickets to visit the main scenic spots in parks. These are optional, which gives visitors more flexibility, but most visitors will want the chance to visit them. A good admission fee criteria can stimulate people to make more visits to parks and stay more days.

\section{Recommendations}

After comparison and analysis of national parks in the United States and China, I have identified a series of best practices that will help China's National Park program succeed on the dual goals of biodiversity conservation and community economic development.

\subsection{The Use of Fees and Permits to Generate Park Revenue and Manage Visitor Use}

In the United States, national park visitors are able to visit the backcountry (and 
camp at designated campgrounds). This is possible because US national parks have a long established management system where they issue various permits for a fee (entrance fees, backcountry camping fees, etc.) to those who want to camp in the backcountry. This also allows national parks to manage the total number of people in the backcountry to increase revenue, but to also to make sure that biodiversity conservation is strong and effective, and that visitor use is well managed. Permitting systems also let Park staff know where Park visitors are, in case of emergencies.

For example, parks can establish a permitting system, design more hiking trails, and change the criteria of admission fees. The admission fee for national parks is an important factor. The fees should not increase every year for profit, but rather fees should stay consistent over time, unless federal level funding decreases and fees need to be increased to maintain the integrity of the Parl. Essentially, the park should design tourism planning that would encourage as many visitors as possible to stay in the national park, in hotels that pay a minimal fee for the right to operate within the Park itself. These changes will be helpful to local community economic development, especially in the tourism sector. During GEI's field survey in Sanjiangyuan and Putatso National Parks, some residents told us that developing tourism is a good thing. According to these residents, they live by grazing, but the government is now implementing prohibitions on pasturing that requires a balance between livestock grazing and grassland conservation. These policies limit economic development, so if local residents can find other revenue sources, this will be best for their lives.

\subsection{Community Economic Development in Gateway Communities}

Tourism planning related to gateway communities is important for economic development, and good tourism planning can guide communities in how to best provide strong tourism services, such as lodging, transportation services, restaurants, and guide services, as examples. With good planning, communities can gain knowledge on how to build their hotels and restaurants sustainably, and how to organize the transportation services, guides services, etc. Parks can work with communities, such as the renting outdoor great, boats and others service, transportation service inside national park. More and more National Park visitors can drive the local economic development, while enjoying China's natural and cultural beauty. This is a double win for China.

\subsection{China's Important Role in Supporting Community Economic Development Adjacent to China's National Parks}

In general, China must focus more on communities and their economic development near parks in our newly forming National Park system. This is an important challenge that must be met when China is developing national parks. In the future, the best approach will be for the community and the Chinese government to co-manage national parks. China's national conditions are such that we cannot move all people out of national parks like the United States. The 
communities in the park also have the right to land use, and the park authority cannot sacrifice local people to pursue economic development. It is important that the park have a good relationship with local communities. The most important goal is that China effectively balances environmental, economic, and social goals in National Park planning.

Natural resources belong to everyone, and communities have a right to protect and enjoy them. Community participation is critical to the development of national parks. This is common practice in the United States. Community support is critical to the U.S. National Park system's success, and the very purpose of the parks is to serve the public interest. Communities should participate in National Park decision-making processes (National Environmental Policy Act, 1969). American law also instructs the NPS to seek out and consult with stakeholders (National Parks Omnibus Management Act of 1998) such as visitors, neighbors, American Indians and others with traditional cultural ties to park lands, scientists and scholars, concessionaires, cooperating associations, gateway communities, other partners, and government agencies. Compared with China's management, this is a unique feature of America's national parks.

\subsection{Community-Based Tourism}

In China, the community is the key to the success of national parks. It is a major challenge to get community support and cooperation. In domestic and international research experience, community-based tourism is regarded as a tool for natural resource conservation and community development and is closely associated with ecotourism (Robert M. Davison, Rger W. Harris and Douglas R Vogel, 2005). It is a community-based practice that provides incentives for natural and cultural conservation as well as providing opportunities for improved community livelihood. In the above context, it mentions that the community can produce local and cultural products as tourism souvenirs. Communities can provide the tourism service, such as hotels, restaurants, stores, interpretation, transportation and local products; and also can provide the renting service, such as boats, cars and bicycles etc. For Chinese national parks, this is a good way to improve community economic conditions.

E-Commerce may be one additional way that communities can strengthen the economic development. With the progress of the Internet age, online shopping is more and more popular. E-commerce has entered the community, and the producer and consumer are directly connected by the internet. Thus, local and cultural products around the national park can be sold through networks across the country. The e-market is not subject to space and time constraints. The community is the main producer of e-commerce products, so it will be also the main source of economic development. The Internet provides an information exchange platform for this and has also become a main development means in some communities. E-commerce has become the most popular shopping method in China, with information spread throughout the country via the Internet. In national parks, community-based tourism and e-commerce can play a major 
role to enhance local economic sustainability and the community conservation.

\subsection{Training for Park Managers and Communities}

China's national parks are located in beautiful places, but in general, the surrounding communities near national parks are often relatively poor economically. They are lack of technology to develop other livelihoods. And local communities have lots of good ideas, but they lack a strong understanding of the role they can play in protecting National Parks and improving economic development. So, the training is vital for them. Park manager or NGOs can organize training in the name of projects. Communities can learn how to conserve the environment and develop the economy through the training. Park managers must be trained with relevant skills to learn how to effectively manage the park, how to work with communities, and how to balance between conservation and local economic development. Park managers also need to learn how to apply relevant science into their decision making, and to be successful in this type of training National Parks in China will need to train lots of Park staff in a consistent way to make sure national level policies and standards are met across different National Parks. Even though my research did not directly focus on training, it is clear that successful Parks (in the USA and around the world) benefit from well organized, structured, long-term training programs on a diverse set of topics that impact overall management of National Parks.

\subsection{Data Collection and Availability}

During the writing of this paper, I learned there is a big difference for collecting economic databases between China and U.S. I also obtained data on China's national parks in 2015 through GEI's field survey. The American data is from the NPS website. In general, it is very easy to find data on the visitor spending in U.S. National Parks, and other data about national parks in the U.S., and this information is clear and transparent. In China, this type of data is not easily available or systematically collected. We only can find them in the public media and park offices. There is not detailed information on protected areas' website or other resources. The park authority also gave only a general description in the GEI field survey, unlike the NPS statistical tools that can present detailed information. The number of visitors and the total economic revenue of tourism are recorded by the statistics bureau, but visitor spending is not analyzed for hotels, restaurants and other industries. So, GEI propose to establish a tool that specializes in statistics and analysis of community economic data. And park manager needs a tool to collect the data. The tool can tell us what the data says. It will also provide a basis for community development planning and formulating related policies in the future.

\section{Conclusion}

In Chinese national parks, communities are an important factor. They are vital 
and they have the potential to have a positive impact on the success of China's national parks. A National Parks purpose is not only to conserve, but also to promote local community economic development. Communities should also be part of decision making processes for China's National Parks, and communities should be able to share the rights, responsibilities, and obligations to protect the natural resources in the park. So, in China, National Park development needs to focus on the above mentioned priorities: the permitting mechanism, camping, local community economic development from tourism, community-based tourism, training and data collection. These are helpful to establish a good relationship between parks and communities. For the Chinese government and Chinese National Park authorities, supporting biodiversity conservation while also fostering community economic growth poses a tremendous challenge to the success of the new National Park system. If done right, China can create a win-win situation for biodiversity conservation and local economic development for people living within, or near the boundaries of National Parks.

\section{Fund}

Ford Foundation, Bluemoon Foundation, Beijing science and technology plan (Z161100001116017).

\section{Conflicts of Interest}

The authors declare no conflicts of interest regarding the publication of this paper.

\section{References}

[1] Su, Y. (2016) Ten Statements on the First Year of China's National Park, China Thinktanks. http://www.chinathinktanks.org.cn/content/detail/id/2930628

[2] Bureau of Labor Statistics, CPI Inflation Calculator. https://data.bls.gov/cgi-bin/cpicalc.pl?cost1=20.00\&year1=199701\&year2=201404 http://www.nps.gov/training/essentials/html/commercial_services_topic.html

[3] Li, Y.L. and Hunter, C. (2015) Community Involvement for Sustainable Heritage Tourism: A Conceptual Model. Journal of Cultural Heritage Management and Sustainable Development, 5, 248-262. https://doi.org/10.1108/JCHMSD-08-2014-0027

[4] Howe, J., McMahon, E. and Propst, L. (1997) Balancing Nature and Commerce in Gateway Communities. Island Press, Washington DC.

[5] Eagles, P.F.J. and McCool, S.F. (2002) Tourism in National Parks and Protected Areas: Planning and Management. Cabi Publishing, Wallingford.

https://doi.org/10.1079/9780851995892.0000

[6] Ozolina, V. and Auzina-Emsina, A. (2013) Inbound Tourism and Sectoral Development in Latvia. Economics and Business, No. 23, 76-82.

[7] (2015) Yosemite National Park, Entrance and Camping Fee Increase Frequently Asked Questions (Report).

https://www.nps.gov/yose/planyourvisit/upload/feeincrease.pdf

[8] Díaz, M.R. and Rodríguez, T.F.E. (2016) Determining the Sustainability Factors and Performance of a Tourism Destination from the Stakeholders' Perspective. Sustai- 
nability, 8, 951. https://doi.org/10.3390/su8090951

[9] Garder, J. (2015) Background: The Economics of National Parks. National Parks Conservation Association.

https://www.npca.org/articles/832-background-the-economics-of-national-parks\#s $\underline{\text { m.0000m98snjpaxd9mvcy20bk33ylcw }}$

[10] Thomas, C.C., Huber, C. and Koontz, L. (2014) National Park Visitor Spending Effects: Economic Contributions to Local Communities, States, and the Nation Natural Resource Report NPS/NRSS/EQD/NRR—2015/947, Fort Collins, Colorado, 2015.

[11] Wang, S.H., Guo, F.B., Russ, A., Cheng, X.P. and Wu, C. (2016) Camping in the US: Inspiration for China. World Regional Studies, 25, 115-124.

[12] Thomas, C.C., Huber, C. and Koontz, L. (2013) National Park Visitor Spending Effects, Natural Resource Report NPS/NRSS/EQD/NRR-2014/824, Fort Collins, Colorado, 2014.

[13] Zeng, X.L. and Hui, T.-K. (2016) Residents' Quality of Life and Attitudes toward Tourism Development in China. Tourism Management, No. 57, 56-67.

[14] Yosemite National Park, Entrance and Camping Fee Increase Frequently Asked Questions (Report) (2015)

https://www.nps.gov/yose/planyourvisit/upload/feeincrease.pdf

[15] Stynes, D.J. (2011) Economic Benefits to Local Communities from National Park Visitation and Payroll, 2010. Natural Resource Report NPS/NRSS/EQD/NRR—2011/481. National Park Service, Fort Collins, Colorado.

[16] Rocky Mountain National Park (1975) Backcountry Management Plan.

[17] Zhao, X.S. (2015) The Explanation from "Nine Provinces Pilots" of China's National Park. Oriental Outlook, 20 August 2015. http://www.lwdf.cn/article_1523_2.html

[18] Su, Y. (2016) National Park Is Not an Upgraded Version of the Nature Reserve. China Development Observation, 16, 45-49+41.

http://d.drcnet.com.cn/eDRCnet.common.web/DocSummary.aspx?chnid=2002\&lea fid=22189\&docid $=4424171$ \&uid $=020210$ \&version=integrated

[19] China's State Forestry Administration, Inexpensive US National Park. 4 August 2014, http://www.forestry.gov.cn/Zhuanti/content_201408gjgyjs/700679.html

[20] Medina-Muñoz, D.R., Medina-Muñoz, R.D. and Gutiérrez-Pérez, F.J. (2016) The Impacts of Tourism on Poverty Alleviation: An Integrated Research Framework. Journal of Sustainable Tourism, 24, 270-298. https://doi.org/10.1080/09669582.2015.1049611

[21] Liu, Q. (2014) China Reforms National Parks to Improve Environmental Protection. China Dialogue, 11 July 2014.

https://www.chinadialogue.net/article/show/single/en/7467-China-reforms-national -parks-to-improve-environmental-protection

[22] Thomas, C.C. and Koontz, L. (2016) 2015 National Park Visitor Spending Effects: Economic Contributions to Local Communities, States, and the Nation, Natural Resource Report NPS/NRSS/EQD/NRR-2016/1200.

[23] Thomas, C.C. and Koontz, L. (2017) 2016 National Park Visitor Spending Effects: Economic Contributions to Local Communities, States, and the Nation, Natural Resource Report NPS/NRSS/EQD/NRR-2017/1421.

[24] NPS (2017) The Statistics Tool of Visitor Spending in NPS Website. https://www.nps.gov/subjects/socialscience/vse.htm

[25] Seligsohn, D. (2015) Report on US National Parks. (Unpublished) 
[26] Thomas, C.C., Huber, C. and Koontz, L. (2014) 2012 National Park Visitor Spending Effects, Natural Resource Report NPS/NRSS/EQD/NRR-2014/765, Fort Collins, Colorado.

[27] Davison, R.M., Harris, R.W. and Vogel, D.R. (2005) E-Commerce for Community-Based Tourism in Developing Countries. 9th Pacific Asia Conference on Information Systems (PACIS 2005), Bangkok, Sections 1-8 and Poster Sessions 1-6, 1396-1403.

[28] National Bureau of Statistics of the People's Republic China, 2015 Statistics Bulletin of the National Economic and Social Development, 29 February 2016.

[29] Xu, W.G., Gao, J., Xia, X., Zhou, D.Q., Li, Z.L., Jiang, M.K. (2004) Distribution of Community Residents in Nature Reserves and Its Impacts on the Reserves in China. Science \& Technology Review, 9, 31-34.

[30] US's National Park Service, Presentation in National Park International Conference, Beijing, China, 26 October 2015.

[31] Beunen, R., Regnerus, H.D. and Jaarsma, C.F. (2008) Gateways as a Means of Visitor Management in National Parks and Protected Areas. Tourism Management, 29, 138-145. https://doi.org/10.1016/j.tourman.2007.03.017

[32] National Park Service, NPS Commercial Services, accessed 28 September 2015.

[33] Yang, R. (2014) Nine Relationships in the Construction of China's National Park System. Chinese Landscape Architecture, No. 8, 5-8.

[34] Meng, X.M. (2007) Management Experience of American National Park System. World Forestry Research, No. 1, 75-79.

[35] Guo, T. (2016) What Is the Difficult Problem in Chinese National Park? Chinese Environment News (Online Journalism).

http://www.cenews.com.cn/opinion/gdftx/201601/t20160118_801494.html

\section{Abbreviations}

GEI: Global Environment Institute

NP: National Park

U.S.: United States

USA: The United States of America

NRDC: National Development and Reform Commission of China

NPS: National Park Service

RMB: Ren Min Bi

RV: Recreational Vehicle

USD: USA dollar

NGO: Non-Government Organization 